\title{
Training Mold Exploring of Private Application-Oriented Institutes for Shaanxi Institute of International Trade \& commerce
}

\author{
ZHAO Li* \\ Xi Xian New Area Logistics \\ Business college Shaanxi Institute of International \\ Trade\&commerce \\ Xianyang, China \\ e-mail: zhaoli0108@163.com \\ * Corresponding Author
}

\author{
HOU Wei-gang \\ Department of Business \\ Business college Shaanxi Institute of International \\ Trade\&commerce \\ Xianyang, China \\ e-mail: houweigang1@163.com
}

\begin{abstract}
The current training mold of private applicationoriented institute is analyzed in this paper. By taking the Shaanxi Institute of International Trade \& commerce for example, the problems during the training of applicationoriented talents are presented. The shortages in the course of development are found that contains unclear target location, unreasonable curriculum system, and inadequate attention to practice teaching. According to these shortages, the interior reasons are analyzed from the current situation of training mold. Then some improvement measures are proposed, in terms of locating in the application-oriented target, optimizing the curriculum system, strengthening the practical teaching, and reforming the grade evaluation. At last, the academician talents training mold explored in the example of this paper is fit for other private applicationoriented institutes in China.
\end{abstract}

Keywords- private institutes; application-oriented institutes, training mold; university-industry collaborations; Shaanxi institute of international trade\&commerce.

\section{INTRODUCTION}

Currently, because the development of social economy requires a lot of advanced application-oriented talents in our country, some private institutes, especially universityindustry $^{[1-5]}$ are located in the application-oriented rationally. Due to not deep thinking in application-oriented institutes, the theory for develop is lacked and the practice for validation is limited to follow the foreign ${ }^{[6-8]}$ blindly. All of that is reflected in the fragmentation and random grafting of college students' training scheme. It is primary that the design of personnel training program exists flaws. Therefore, through building the new type applied undergraduate major by location scientifically, how to cultivate the distinctive characteristic and advantage competition applied talents with high quality, is an issue needed to be discussed deeply for applied private institutes.

\section{SHAANXI INSTITUTE OF INTERNATIONAL TRADE \& COMMERCE}

Shaanxi Institute of International Trade\&Commerce is founded by Xianyang Bu Chang Group in May 1997. At the beginning of the establishment, the college is first called for Shaanxi international trade specialty college.
Until June 2002, it is changed to be Shaanxi international business vocational college. The current name is named in May 2008. It is remarkable worth to state that the Bachelor degree is obtained in May 2012 and is changed to carry out the general education ${ }^{[9]}$.

After nearly twenty years development, the institute is consist of eight secondary colleges. It contains Business college, financial and accounting college, medicine college, information and engineering college, culture and art college, international economics college, jewellery college and fashion technology college. Now it is total 21 undergraduate majors and specialists, which cover six disciplines, including the economics, management science, medicine, engineering, literature, art and so on. The institute adheres to the school philosophy of local, application-oriented, characteristics.

By relying on $\mathrm{Bu}$ Chang Group, the s universityindustry collaborations mode ${ }^{[3-5]}$ is explored. The institute emphasizes association with market demand, and signs with several large enterprises about the cooperation agreement. Now the experts form these enterprises are invited to participate in the designing of college students' training scheme, co-constructing the professional laboratory, and building the practice bases. All the measures are used to reach the object of linking up with social and economic development and mixing together with enterprise employment. At the same time, many enterprise senior engineer and technical personnel are employed as the practice guidance teachers of the institute, which facilitates the training of manipulative ability and applied talent required by the social and enterprise. As development in the new $21^{\text {st }}$ century, the future objective of Shaanxi Institute of International Trade \& Commerce is to construct the high level application-oriented university.

\section{ANALYZING THE CURRENT SITUATION OF TRAINING MOLD}

\section{A. Unclear target location}

Currently, private application-oriented institutes are in difficult situation in China. It is presented with two aspects. On the one hand, the academic research is much poor than the other famous universities. On the other hand, the 
students' manipulative ability is worse than the vocational colleges of the same kind. The reason is that the location of talents training target is not clear.

In spite of Shaanxi Institute of International Trade \& Commerce is established for more than ten years, the orientation and characteristic has been neglected in the beginning design stage. On the contrary, the main energy is used to grow the institute. To formulating the training target, some schemes of the famous university are referenced. However, the measure directly leads to the same distribution between the same majors in other colleges of the same kind. It is a tendency to homogeneity and lack of features.

\section{B. Unreasonable curriculum system}

In the 2012 version of undergraduate personnel training scheme, the curriculum includes public basic courses, professional basic courses, specialized courses and elective courses, which is shown in Fig. 1. All these courses have their function with good starting point.

- The basic courses are mainly to enhance students' basic skills and train the quality of students.

- The professional basic courses are to expand students' knowledge and joint later courses.

- The specialized courses are used to enable students to master the skills and train professional quality.

- The elective courses are set mainly on the basis of the students' interesting.

After several years of operation, many problems occur outside. In all, there are four outstanding issues in the curriculum.

- The public basic course is set too much and miscellaneous. Taking the marketing major as an example, its public basic courses are about $43.4 \%$ proportion comparing with the total teaching courses.

- The lessons arrangement of specialized courses is unreasonable, which leads to incompletely cover the necessary knowledge. It does not come up to one third comparing the marketing specialized courses with the total teaching hours, which is obviously unreasonable.

- The curriculum system is not perfect and planned unreasonable. By adopting three terms into undergraduate personnel training scheme, the weeks in the former three years are declined from

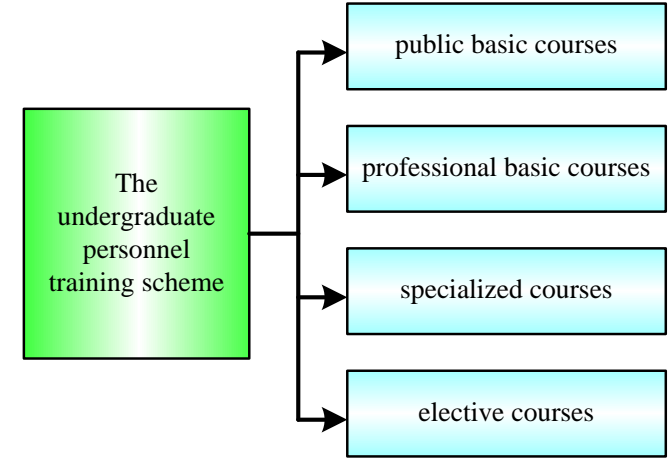

Figure 1. The undergraduate personnel training scheme in the 2012 version.

20 to 14 . At the same time the summer term is increased by 6 weeks.
- At last, the situation that setting different course for different teacher is widely presented.

\section{Inadequate attention to practice teaching}

It is a common phenomenon that the emphasis on the theory but neglect of practice in private undergraduate colleges and even most universities. It is remarkable that the talent trained in this mold has better theoretical expertise, relatively poor ability to actual use, which is lack of innovative capacity. There is a certain gap between requirements of enterprises and institutions on the practical operation.

There are many reasons for this phenomenon, influenced by either the Chinese traditional education universities or the teachers' own factor. For the experimental teaching, it is always in a subordinate position in curriculum system of colleges. Both experiment management system and the experimental curriculum don't get enough attention. The history of establishment of the institute is short and the most recruiting teachers are fresh master graduates. These teachers have more solid theoretical foundation, reasonable knowledge structure. But it is needed to notice that their practical ability is poor and experimental teaching is weak, which cannot ensure the quality of practice teaching.

In the 2012 version of undergraduate personnel training scheme, the week numbers in the teaching works is distributed in Table I. From Table I, it can be obtained that, the spring season carries out the regular classroom instructions, but the summer season changes to practice training. The varying proporation is $30 \%$. However, the quality of practice teaching is used to be theory teaching directly. The teaching content is divorced from reality through developing the practice training.

TABLE I. THE WEEK NUMBERS DISTRIBUTION IN THE 2012 VERSION

\begin{tabular}{|c|c|c|}
\hline School Years & School Terms & $\begin{array}{c}\text { Week } \\
\text { numbers }\end{array}$ \\
\hline \multirow{3}{*}{ The first year } & The autumn season & 19 \\
\hline & The spring season & 14 \\
\hline & The summer season & 6 \\
\hline \multirow{3}{*}{ The second year } & The autumn season & 21 \\
\hline & The spring season & 14 \\
\hline & The summer season & 6 \\
\hline \multirow{3}{*}{ The third year } & The autumn season & 21 \\
\hline & The spring season & 14 \\
\hline & The summer season & 6 \\
\hline \multirow{2}{*}{ The fourth year } & The autumn season & 21 \\
\hline & $\begin{array}{l}\text { The spring and summer } \\
\text { season }\end{array}$ & 18 \\
\hline Total & \multicolumn{2}{|l|}{160} \\
\hline
\end{tabular}




\section{IMPROVEMENT MEASURES OF TRAINING MOLD}

\section{A. Locating in the application-oriented target}

At the crucial moment, Chinese new round of adjustment and restructuring of higher education is activated. The institute issued a programmatic document, Shaanxi Institute of International Trade \& Commerce Top Design, for the restructuring and development in 2014. The document clearly stated objective of talent training is, firstly to adapt to the requirements of the national or local economic and social development, secondly to accord to the requirements of industry and business, and thirdly to train the high-quality application-oriented talents with good ideological, cultural qualities and occupation accomplishment, strong sense of social responsibility, solid foundation of knowledge and basic skills, strong learning ability, practical ability and sense of innovation, compliant requirements of the production, management and service.

\section{B. Optimizing the curriculum system}

The institute revised 2012 version of undergraduate training scheme in 2014 referred to the foreign university model in [10-12]. The main proposed construction ideas of curriculum system is to set up the curriculum system by taking the professional corresponding career clusters or knowledge, technical and skills required by sectors as the center. It is strive to reach that the basic courses are applicable, the professional basic courses are effective, the specialized courses contact with theory and the elective courses are increased. More learning autonomy and choice are provided for students. The general education, professional education and self-development are combined organically. The space for the future diversification of the student is provided adequately. The 2014 version of undergraduate training scheme adopts 'Platform + Module' curriculum system, which is shown in Fig. 2.

In Fig. 2, the curriculum system consists of the general education platform, the professional education platform, the practice education platform and the ability expanding platform. A platform consists of several different modules. At the same time, the lessons of curriculum are constrained in the aspects of class hours. The proportion of general education platform courses is not more than $30 \%$ (elective courses of quality education accounts for about 5 percent). The proportion of professional education platform course is not less than $30 \%-35 \%$. The proportion of practice education platform course is not less than $6 \%$. The ratio of compulsory and optional course is 7:3. Elective courses contain quality education elective courses, professional elective courses and professional direction courses of limited selection.

\section{Strengthening the practical teaching}

In order to highlight the application-oriented talents training objectives, the 2014 version of undergraduate training program set up the practice education platform, build the practical teaching curriculum system called 'a main line, four stages, dynamic style, diversification, choose'.

- 'A main line' refers to that the practical teaching is always around the students' ability of practical application.

- 'Four stages' is defined as the basic practice stage, comprehensive improvement stage, practical training stage and professional competence stage in the practical teaching.

- 'Dynamic style' refers to the teaching contents characteristics of the times.

- 'Diversification' refers to the practical teaching in line with education thinking of individualized and personalized training.

In addition, the cumulative class hours in practical teaching are required as follows: humanities and social science majors are not less than $20 \%$ of total hours, science majors are not less than $25 \%$ of total hours, engineering majors are not less than $30 \%$ of total hours, Liberal arts are no less than 30 weeks, science majors are no less than 35 weeks and engineering majors are not less than 40 weeks in centralized practical teaching.

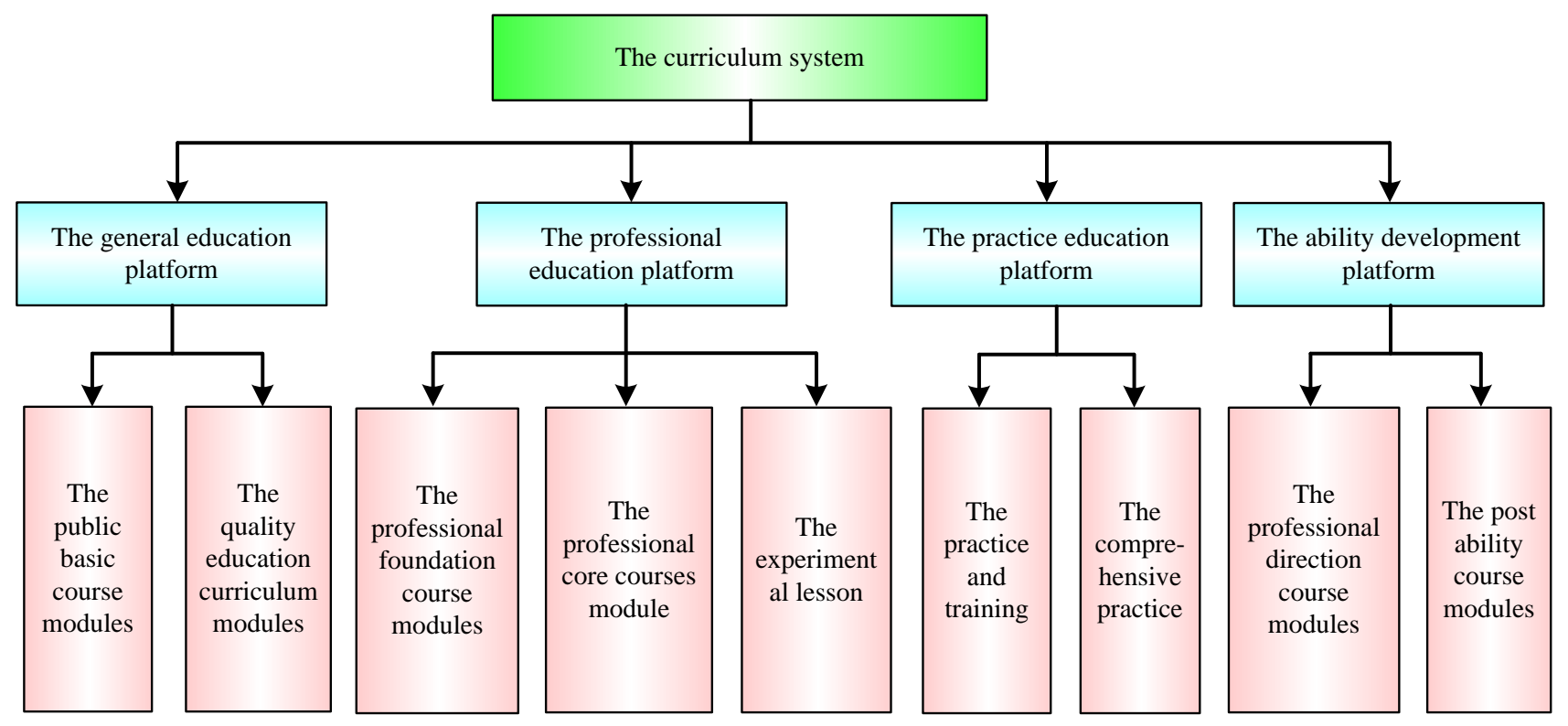

Figure 2. The 'Platform + Module' curriculum system in the 2014 version. 


\section{Reforming the grade evaluation}

Assessment system is directly related to style construction and the quality of teaching. The 2014 version of undergraduate training scheme is mentioned that, to strengthen the teaching process assessment, to promote innovation of assessment methods, to encourage teachers to take various forms of assessment based on major characteristics, to present the nature of the curriculum and teaching objectives so as to enhance actual effect of the assessment.

At the same time, it is needed to increase the proportion of process test results and strengthen the assessment and evaluation of the usually learning status of students and stage learning outcomes. The assessment of the professional elective courses can take the method of exchanging professional qualifications for corresponding credits of the course. It is the principle that the elective courses should be arranged no more than six in each semester.

\section{CONCLUSION}

For the private application-oriented institutes carrying out the reform of application-oriented talent training mode by the opportunity of transformation, it has very important significance to enrich the theory of higher education development and promote institutes development harmoniously. It is the only way of development of private undergraduate institutes. In this paper, the training mold exploring of private application-oriented institutes is researched by taking Shaanxi Institute of International Trade\&commerce as an example. Because different universities are in various types of location, talents training mode varies differently. If the private application-oriented institutes want to train appropriate required talents, they cannot look forward to a noble steed according to its picture, by copying the teaching mode of old universities and cloning their education path.

After sufficient analysis, it can be obtained that the best way is to carry out application-oriented reform. The single effective pattern is to realize reasonable location, overcome tendency of the homogenization, form their own educational philosophy and style, characterize at different levels and in different areas.

\section{ACKNOWLEDGEMENT}

This research was financially supported by the Natural Science Foundation of Shaanxi provence (Grant No. 81203573) and the Fundamental Research Funds for Shaanxi Province Education Science 'Twelfth Five-years Plan' (Grant No. SGH140865).

\section{REFERENCES}

[1] Hanna Lehtimaki and Tuomo Peltonen, "Relations of power and knowledge: university-industry relations in business studies in Finland", Higher Education Policy, Vol. 66, No. 2, pp. 203-216, 2013

[2] Muhammad Fiaz and Baseerat Rizran, "Erratum: universityindustry ecosystem: factors for collavorative environment", Communications in Computer and Information Science, Vol. 257, p E1, 2011.

[3] Giorgio Calcagnini, Germana Giombini, Paolo Liberati and Giuseppw Travaglini, "A matching model of university-industry collaborations", Small Business Economics, 2015. (online)

[4] Muscio A and Pozzali A, "The effects of cultural distance in university-industry collaborations: some evidence from Italian unversities", The Journal of Technology Transfer, Vol. 38, No. 4, pp. 486-508, 2013.

[5] Lori Turk Bicakci and Steven Brint, "University-industry collaboration: patterns of growth for low and middle level performers", Higher Education, vol.49, No. 1-2, pp. 61-89, JanMar 2005.

[6] EIzabeth J. Hatton, "Charles sturt university: a case study of institutional amalgamation", Higher Education, Vol. 44, No. 1, pp. 5-27, 2002.

[7] Drek Bok, University in the market place, Princeton University Press, 2003, pp. 1-62.

[8] James J. Dudersdadt, A university for the 21st Century, the Uni versi ty of Michigan Press, 2000, pp. 1-33.

[9] Peter Scott, "The future of general education in mass higher education system", Higher Education Policy, Vol. 15, No. 1, pp. 61-75, 2002.

[10] L. R. Becker, "The impact of university incorporation on college lecturers", Higer Education, Vol. 48, No. 2, pp. 153-172, 2004

[11] Sven-Eric Liedman, "A lesson for life", Studies in Philosophy and Education, Vol. 21, No. 4-5, pp. 313-333, 2002.

[12] Marta Lenartowicz, "The nature of the university", Higher Education Policy, Vol. 69, No. 6, pp. 947-961, 2015. 